\title{
Scenario of electricity trading in South Asia: Perspective and feasibility of trading between India and Bangladesh
}

\author{
Anmona Shabnam Pranti ${ }^{1}$, Arif Mohammad Shahed Iqubal ${ }^{2}$, Mohammad Shawkut Ali Khan ${ }^{2}$, \\ Mohammad Kayesar Ahmmed ${ }^{3}$ \\ ${ }^{1}$ Department of Electrical and Electronics Engineering, International University of Business Agriculture and Technology, Dhaka, \\ Bangladesh \\ ${ }^{2}$ Department of Mechanical Engineering, International University of Business Agriculture and Technology, Dhaka, Bangladesh \\ ${ }^{3}$ Greenland Builders Limited, Dhaka, Bangladesh
}

\section{Email address:}

Anmona.s.p@iubat.edu (A. S. Pranti), iqubal.shahed@iubat.edu (A. M. S. Iqubal), shawkut.ali@iubat.edu (M. S. Ali Khan), maks_eee_cuet@yahoo.com (M. K. Ahmmed)

\section{To cite this article:}

Anmona Shabnam Pranti, Arif Mohammad Shahed Iqubal, Mohammad Shawkut Ali Khan, Mohammad Kayesar Ahmmed. Scenario of Electricity Trading in South Asia: Perspective and Feasibility of Trading between India and Bangladesh. American Journal of Electrical Power and Energy Systems. Vol. 2, No. 6, 2013, pp. 156-165. doi: 10.11648/j.epes.20130206.16

\begin{abstract}
Uninterrupted electricity supply is the precondition of economic development of a country. Bangladesh has huge electrical power deficiency and to minimize this lagging, Government is importing $250 \mathrm{MW}$ electrical power from India. India is itself an electricity deficiency country and has already relationship of trading with two south Asian countries, but the policies of those trading are not beneficial for those respective countries. On the other hand Bangladesh is richer than many other south Asian countries in respect to primary energy reserve. Proper management of this primary energy and electricity sector, to produce and use electricity properly could be a good solution of running electricity scarcity problem of Bangladesh. In some context inter-countries trading is important in south Asia to have a sustainable economic growth when it is beneficial and preserve the right for both countries. Purchasing power from India cannot be a fruitful solution because it will increase our dependency on them. By this trading we may reduce the electricity crisis instantly but could be a cause of long term negative effect on our overall economy. Moreover most of the energy specialists and learned people have negative opinion about this electricity trading. This trading cannot be the good and permanent solution to solve power scarcity problem of this country. Bangladesh should try to be self sufficient in electrical power by proper management and utilization of its own resources instead of spending money for purchasing power from India.
\end{abstract}

Keywords: Electricity Trading, South Asia, India-Bangladesh

\section{Introduction}

Electricity is an essential element of modern living and key of Economic and social development in an industrial country. Our personal and professional life activities like communication, transportation, basic and luxurious equipments entirely depend upon sufficient supply of electricity at cheap rate. So uninterrupted electricity supply at considerable rate is the precondition of national development and Government's constitutional duty which has not been proved yet. Though electricity is considered as a primary right, the people of Bangladesh are far away from this because of the destruction of electricity sector. The industries are the heart of economy, sometimes it becomes difficult for industrial and developing countries like
Bangladesh to supply sufficient electricity by setting power plant as it needs time, huge investment, and fuel reserve. As Bangladesh is trying to become a middle income country within 2022 [68], Government is taking different strategies to minimize the difference between demand and supply of electricity and importing electricity from India is one of them. The regional cooperation is necessary for development and to strengthen South Asian union, country and their motto of cooperation, long term economic analysis, political assessment and public opinion are important as people are the owner of all resource. People may have different thoughts and argument on $25 \mathrm{MWh}$ electricity import from India from August 2013 [68]. This paper has shown feasibility of this electricity import especially from India on the basis of regional energy and energy exchange 
analysis and survey on people opinion.

\section{Literature Review}

An agreement of power transmission for 35years between India and Bangladesh for importing $250 \mathrm{MW}$ of electricity to Bangladesh was made in July 2010 by the Bangladesh Power Development Board (BPDB) and Power Grid Company of India Ltd. (PGCIL)[73,67,72]. BPDB will pay power and transmission tariff according to the decision of India's Central Electricity Regulatory Commission (CERC)[73,67,72]. Power Secretary of Bangladesh has declared that the government of Bangladesh is going to import $250 \mathrm{MW}$ of electricity from India at 4 taka per Kwh (without transmission line cost) and the power secretary of India has confirmed the completion of transmission line installation within this July $[73,67,72]$. As Bangladesh wants to be a middle income country by 2022, Government is importing electricity from India since August 2013. For this purpose grid connection between Bheramare (Bangladesh) and Behrampur (India) has been constructed according to the meeting of Ministers Dipu Moni and Salman Khurshid in Dhaka[74,67]. Bangladesh has to buy this $250 \mathrm{MWh} /$ day electricity from India [74]. Moreover, a joint coal based power plant (Bangladesh-India) of $1320 \mathrm{MW}$ is being constructed at Rampal, Bangladesh and will start in 2017 under the supervision of Bangladesh Power Development Board and National Thermal Power Company of India according to the agreement of August, 2010 at $50 \%$ ownership for each[74,69,67,70].

Bangladesh government has constructed $400 \mathrm{KV}$ high voltage transmission line for importing 500MW of electricity according to the decision of Prime Minister Level meeting [69]. On the other hand, the government of India now has committed to supply only $250 \mathrm{MW}$ of electricity from 'Unallocated Resource' at low cost and said that Bangladesh can import another $250 \mathrm{MW}$ of electricity in future from 'Power Pool' of India [69,72]. The length of the transmission line between Bheramara and Behrampur is $125 \mathrm{~km}$ of which $40 \mathrm{~km}$ is inside Bangladesh area and transmission voltage level are $230 \mathrm{KV}$ and $400 \mathrm{kV}$ respectively with a capacity of $500 \mathrm{MW}$ [72]. The total construction cost of this transmission line is 82.2 billion INR of which India paid only 17.8 billion INR and Bangladesh had to pay 64.4 billion INR [72].

Most of the existing transmission line of Bangladesh is of $132 \mathrm{KV}$. For supplying the imported power at $230 \mathrm{KV}$ voltage level, new transmission line has to be built and a tender was invited by Power Grid Company Bangladesh to construct transmission line of $30 \mathrm{~km}(400 \mathrm{Kv}$ and $230 \mathrm{Kv}$, Ishurdi-Khulna); $165 \mathrm{~km}$ (230 kV, Bibyana-Comilla) and a HVDC line at Bheramara [72]. \$100 million loan was approved by Asian Development Bank (ADB) for cross-border transmission line construction [72]. But the loan had not been got because of the problem in power purchase agreement between BPDB and the NTPC Limited [72]. Moreover, Bangladesh's Planning Commission had to pros pond the project because India did not guarantee the power supply [72]. Power Grid Company Bangladesh is giving 1 billion BDT to a Spanish company to construct the transmission line of Bangladesh portion and $\$ 170$ million to Siemens to construct a converter station at Bheramara to convert $400 \mathrm{Kv}$ from India to $230 \mathrm{Kv}$ to Bangladesh [72]. For greater trade with India, PGCB has constructed another $500 \mathrm{MW}$ substation at Bheramara [72].

\section{Proposed Line}

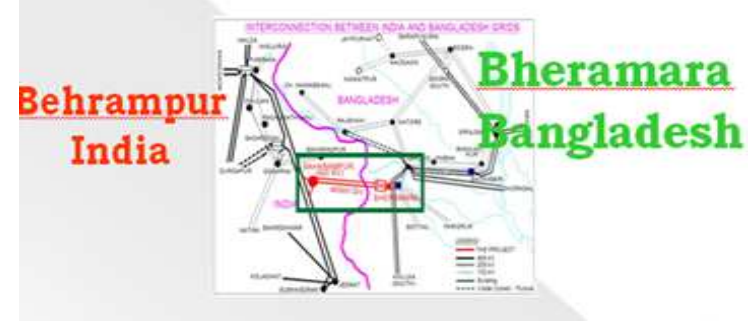

Figure 1. proposed construction line from Behrampur to Bheramara

According to the MoU signed by the Government of Bangladesh and Myanmar, Bangladesh will be able to import $500 \mathrm{MW}$ of electricity from Lemro river of Rakhain state, Myanmar by 2018 [69].

Nepal is always willing to share of its' hydro electricity resource of $40000 \mathrm{MW}$ with the neighbors for the benefit of this region and Nepalese Ambassador to Bangladesh said that Nepal is interested to export hydro power in Bangladesh [71]. He also said that though Nepal has huge hydro electric potential, Bangladesh cannot use this because of a gap in trade relationship and both countries have to move forward to minimize the gap by establishing physical connectivity [71].

\section{Energy Security, Electricity and Fuel Relationship for Economic Development of Bangladesh}

The education rate, per capita income and expenses, GDP increment rate, standard of living are the main determinants of human development which entirely depend upon per capita electricity use of a country [1,2]. Only $42 \%$ people of Bangladesh get electricity with a rate of only 188 KWh/person [3]. On the other hand, Pakistan (developing country) and USA (developed country) use electricity of $456 \mathrm{KWh}$ and $13640 \mathrm{KWh}$ per capita respectively [3]. 80\% rural people of our country depend on agricultural residue for meeting their energy need [76]. Human life security and sustainable development of a country cannot be earned by unrestricted use of national energy reserve [4]. Though electricity is the best form of energy, it cannot be preserve for future use. Moreover, uninterrupted electricity supply 
depends on secure transmission and distribution system. Current demand and the generation of electricity are 7500MW and 5063 MW respectively [75,68,74]. The government plans to increase the overall capacity up-to $20000 \mathrm{MW}$ by 2021[9]. Current GDP growth rate of Bangladesh is $6.3 \%$ [66]. $7.5 \%$ GDP growth rate is necessary to reduce half of the poverty of Bangladesh and energy use increment rate should be 2.5 times [6]. Electricity scarcity is the main obstructer of the development of Bangladesh. From 1973 to 2006, increment of GDP growth rate is lower than increment of per capita electricity use rate in Bangladesh [7]. So it is clear that electricity was used for living only rather than using in production purpose and it is seemed that the trend will continue. The imported electricity will use for increasing living standard only.

\section{Comparative Energy Situation and Economics in South-East Asia}

The countries of South East Asia have been developed rapidly in last ten years. But most of these countries cannot meet energy demand for sustaining this development growth. Table below represents the condition of primary and secondary energy for different countries of this region.

975 million people of 1330 million of China are electrified [12,23]. GDP growth rate is $11.4 \%$ [15]. China had 25000MW of electricity deficiency in 2005-06 [22] and imported 5392 million KWh [25] and exported 11270 million KWh [26] in that year. Generally China import electricity from Russia [27] and Export to Vietnam [29]. Now China has taken different strategy of electricity production such as hydro power by creating Dam in Himalayan Rivers and setting their own plant in Kazakhstan, Kirgizstan, Cambodia and Mongolia [28].

Though Bhutan has surplus hydro electricity reserve, it imported 20million KWh electricity from India in 2006 [25]. On the other hand it exported electricity of 1500 million $\mathrm{KWh}$ to India in the same year [30]. The electrification rate is only $60 \%$ [32] and the country has to import Oil and petroleum to meet energy demand [31].

Nepal is also endowed with hydro electricity around $83000 \mathrm{MW}$ [10]. Only 40\% population is electrified [10] and electricity consumption rate is $66 \mathrm{kWh} / \mathrm{cap}$. Instead of having enormous hydro resource, to meet the energy demand it has to import oil (87\%), coal and electricity [31]. It imported electricity of 266 million KWh [25] from India and exported electricity of 101 million KWh [26] to India in 2006. Though there is serious scarcity of electricity, Nepal export electricity and it seems that electricity export revenue could not change the economic condition of the country.

Though Sri Lanka does not have sufficient primary energy and hydro potential reserve, $78.1 \%$ people are electrified [35]. Sri Lanka does not import electricity; only import primary energy to produce electricity to obtain $\$ 1195 /$ capita GDP [14] which is the second highest in South Asia.

Table 1. Primary and Secondary Energy reserve in South Asian Countries

\begin{tabular}{|c|c|c|c|c|c|c|c|c|c|c|c|c|c|c|c|c|}
\hline \multirow[b]{2}{*}{ Country } & \multicolumn{2}{|c|}{ Population } & \multicolumn{7}{|c|}{ Primary Energy } & \multicolumn{3}{|c|}{$\begin{array}{c}\text { Electricity } \\
\text { (million KWh) }\end{array}$} & \multicolumn{2}{|c|}{$\begin{array}{l}\text { Per capita } \\
\text { consumption }\end{array}$} & \multicolumn{2}{|c|}{ Per capita GDP } \\
\hline & $\begin{array}{l}\text { Populati } \\
\text { on in } \\
\text { million } \\
{[12]}\end{array}$ & $\begin{array}{l}\text { increme } \\
\text { nt } \\
\text { rate } \% \\
{[13]} \\
\end{array}$ & $\begin{array}{l}\text { Oil [17] } \\
\text { bbl }\end{array}$ & $\begin{array}{l}\text { Gas } \\
\text { (tcf) }\end{array}$ & $\begin{array}{l}\text { Coal } \\
\text { (MT) }\end{array}$ & $\begin{array}{l}\text { Nuclear } \\
\text { Energy } \\
\text { (ton) }\end{array}$ & toe/cap & $\begin{array}{l}\text { Hydro } \\
\text { MW }\end{array}$ & $\begin{array}{l}\text { Hydro } \\
\text { W/cap }\end{array}$ & $\begin{array}{l}\text { Consum } \\
\text { ption } \\
{[76]}\end{array}$ & $\begin{array}{l}\text { Import } \\
{[25]}\end{array}$ & $\begin{array}{l}\text { Export } \\
{[26]}\end{array}$ & KWh & Kg oe & $\begin{array}{l}\text { US } \\
\$[14]\end{array}$ & $\begin{array}{l}\text { growth } \\
\text { rate } \\
{[15]}\end{array}$ \\
\hline China & 1330.04 & 0.63 & 12800 & $\begin{array}{c}66.54 \\
{[42]}\end{array}$ & $\begin{array}{c}114500 \\
{[18]}\end{array}$ & $\begin{array}{c}68000 \\
{[19]}\end{array}$ & 374.73 & $\begin{array}{c}165000 \\
{[24]}\end{array}$ & 124 & 2859000 & 5390 & 11270 & 2150 & $1075[33]$ & 3174 & 11.4 \\
\hline India & 1148.00 & 1.58 & 5848 & $\begin{array}{c}37.26 \\
{[42]}\end{array}$ & $\begin{array}{c}92445 \\
{[18]}\end{array}$ & $\begin{array}{c}73000 \\
{[19]}\end{array}$ & 448.41 & $\begin{array}{c}143311 \\
{[32]}\end{array}$ & 130 & 488500 & 1764 & 286 & 426 & $351[34]$ & 1078 & 8.5 \\
\hline Pakistan & 167.76 & 1.81 & 289.20 & $\begin{array}{c}30.02 \\
{[42]}\end{array}$ & $\begin{array}{l}3300 \\
{[18]}\end{array}$ & $\begin{array}{l}6000 \\
{[21]}\end{array}$ & 240.32 & $\begin{array}{c}17369 \\
{[32]}\end{array}$ & 248 & 67060 & 0 & 0 & 400 & 337 [35] & 931 & 6.3 \\
\hline Bangladesh & 153.55 & 2.02 & 28 & $\begin{array}{c}13.77 \\
{[42]}\end{array}$ & $\begin{array}{l}2221 \\
{[44]}\end{array}$ & - & 10.86 & $\begin{array}{l}555 \\
{[10]}\end{array}$ & 3.6 & 19490 & 0 & 0 & 127 & $117[36]$ & 541 & 6.0 \\
\hline Afghanistan & 32.74 & 2.63 & - & $\begin{array}{c}1.678 \\
{[16]}\end{array}$ & $\begin{array}{l}100 \\
{[39]}\end{array}$ & - & 3.04 & $\begin{array}{c}183.35 \\
{[38]}\end{array}$ & 6 & 800 & 100 & 0 & 24 & 12 [37] & 393 & 7.5 \\
\hline Sri Lanka & 21.13 & 0.94 & - & - & - & - & - & $\begin{array}{l}2000 \\
{[10]}\end{array}$ & 95 & 7070 & 0 & 0 & 335 & $195[38]$ & 1195 & 6.0 \\
\hline Nepal & 29.52 & 2.10 & - & - & - & - & - & $\begin{array}{c}83290 \\
{[10]}\end{array}$ & 2776 & 1960 & 266 & 101 & 66 & 45 [39] & 428 & 2.5 \\
\hline Bhutan & 0.68 & 1.30 & - & - & - & - & - & $\begin{array}{c}30000 \\
{[10]}\end{array}$ & 44118 & 380 & 20 & 1500 & 559 & $63[40]$ & 2005 & 8.8 \\
\hline Maldives & 0.38 & 2.69 & - & - & - & - & - & - & - & 160 & 0 & 0 & 421 & 808 [41] & 3358 & 5.5 \\
\hline Myanmar & 47.77 & 0.80 & 1963 & $\begin{array}{l}9.59 \\
{[16]}\end{array}$ & $\begin{array}{c}258.11 \\
{[20]}\end{array}$ & - & 13.51 & $\begin{array}{c}108000 \\
{[32]}\end{array}$ & 2260 & 3740 & 0 & 0 & 78 & 82 [42] & 287 & 5.5 \\
\hline
\end{tabular}


Afghanistan imports electricity of $4 \mathrm{MW}$ from Iran, 5 MW from Kazakhstan, $150 \mathrm{MW}$ from Uzbekistan and 8 MW from Turkmenistan [22]. It imported $96 \mathrm{MW}$ of electricity in 2007 [39].

Instead of having no primary energy reserve and hydro potential, the per capita electricity consumption of Mal dives is $421 \mathrm{KWh}$. Moreover, they have planned to generate 232.5 MW wind electricity and to set half kilometer solar panel [40]. So Maldives is developing rapidly without importing any electricity.

Pakistan has sufficient primary energy reserve and the coal reserve is the $6^{\text {th }}$ highest in the world along with nuclear energy reserve [31]. 36.8\% produced gas is used in electricity generation and $33.4 \%$ generated electricity comes from hydro power plant [31]. Instead of having 40316.08 Mtoe primary energy and 41722 MW hydro electricity reserves [32], Pakistan is going to import electricity from Iran, Tajikistan and Uzbekistan in near future [43].

$88.45 \%$ electricity generation of Bangladesh is dependent on Natural gas [44] and 0.5 million ton coals is used to produced 250 MW electricity each year [31]. Though Bangladesh has 2221 million ton high grade coal reserve, it cannot be used properly due to lack of technological support [44]. Electricity production from oil and hydro potential is negligible and the government has not taken proper steps to enhance electricity sector yet.

India can meet its $70.73 \%$ energy demand by its' own energy and it has to import Gas, Coal, Oil and Hydro electricity for other $29.27 \%$ [31]. India imported 1764 million KWh and exported 286 million KWh of electricity in 2006-07 [25]. There was electricity deficiency. The above information shows that, India is still not solvent in electricity production for serving its own population.

Myanmar has 10.8 million MW hydro potential reserve and they are producing 35\% (3145 MW) and 55\% of electricity from hydro potential and gas respectively [45, 30]. Myanmar is going to export electricity of $360 \mathrm{MW}$ to Thailand and $1200 \mathrm{MW}$ to India in near future [22].

\subsection{Energy Exchange in South Asian Region}

- Different international monetary organizations think energy cooperation in South Asia will help people to get energy at a cheap rate because of open border energy market which will result technological and economical development of this region [10]. The Energy ministers of SAARC countries decided to create "Energy Ring" for interchanging Gas and Electricity in 2009 in Colombo, Sri Lanka [11]. The decision of energy exchange between South Asian countries has been taken on the basis of following reasons:[11]

- Though some of the South Asian Countries have sufficient energy reserve and there is a possibility of exchanging energy, the countries are amongst the lowest income countries of the world due to low per capita energy use.

- To obtain sustainable development by using these huge amounts of energy resource, internal relation, cooperation and trust is needed among the governments.

- World Bank stated that it is possible to earn 6.6-11\% GDP growth rate in SAARC region in 15-20 years if "Cross Border Energy Trade" will complete properly [11].

\subsection{Scenario of Existing Cross-Border Electricity Exchange in South Asia}

4.2.1 Exchange between India and Nepal

Table 2. Electricity exchange between Nepal and India (1990-2006) [46]

\begin{tabular}{|c|c|c|c|c|c|c|c|c|c|c|c|c|c|c|c|c|c|c|}
\hline Million KWh & 690 & 991 & 692 & ‘93 & 694 & ‘95 & '96 & ‘97 & ‘98 & ‘99 & '00 & '01 & '02 & '03 & ‘04 & '05 & '06 & Total \\
\hline Export KWh & 23 & 81 & 85 & 46 & 51 & 40 & 87 & 100 & 67 & 64 & 95 & 126 & 134 & 192 & 140 & 113 & 101 & 676 \\
\hline Import & 61 & 34 & 55 & 82 & 103 & 104 & 37 & 154 & 210 & 232 & 232 & 227 & 238 & 150 & 127 & 241 & 266 & 1381 \\
\hline difference & 38 & -47 & 38 & 36 & 52 & 64 & -50 & 54 & 143 & 168 & 137 & 100 & 104 & -42 & -13 & 128 & 165 & 704.9 \\
\hline
\end{tabular}

From the above statistics we can see that, Nepal had to import more electricity from India than export to India in each years and the trend was uprising. Nepal imported electricity of 1381 million KWh, where as exported only 676 million KWh electricity in 17 years. In this trade, Nepal spent 70438.51 million INR for importing and earned 3605.82 million INR for exporting [46]. In 1996, electricity exchange rate was 1.67 INR at $8.5 \%$ increment rate at $230 \mathrm{KV}$ level [46]. According to this, the rate would be 2.96 INR in 2003, 3.10 INR in 2004 and 3.77 INR in 2008 and 3.96 INR in 2009 [46].

Cross border exchange between Nepal and India was started in 1954 after the sign of Kasi MoU with the installation of a $20 \mathrm{MW}$ hydro-electric power plant [46]. According to the MoU, Nepal can buy 50\% (10 MW) of generated electricity at predefined rate. India can get rest of $50 \%$ electricity by only minimum royalty [46]. In 2005-06, Nepal bought electricity of 30 million KWh at a rate 2.38 
INR from its own available hydro potential [46].

According to Mahakali MoU, India set a $120 \mathrm{MW}$ hydro electric power plant at Nepal which can produce 484.4 million KWh/year among which Nepal can get only 70 million $\mathrm{KWh} /$ year of electricity [30]. India will get rest of all [29]. However, Nepal has never got electricity of 70 million KWh from 1990; only get 52.83 million KWh/year of electricity [29].

India agreed to export $150 \mathrm{MW}$ of electricity to Nepal in 2001 but Nepal has to pay extra charge for electricity of higher than $50 \mathrm{MW}$ [46]. Nepal has to lose \$1.44 million for this trade [46]. Moreover, Snowy Mountain Engineering Company has set a $750 \mathrm{MW}$ hydro electric power plant under West-Seti project and all electricity of this project will be exported to India, Nepal will get $90 \%$ royalty money instead of electricity [47]. According to MOU of that project, India imports electricity of 3 billion KWh/year at $0.0496 \$ / \mathrm{KWh}[46]$.

\subsubsection{Exchange Program between India and Bhutan}

Table 3. Electricity generation, use and export from Bhutan to India in between 2000-08

\begin{tabular}{|c|c|c|c|c|c|c|c|c|c|c|}
\hline year & 2000 & 2001 & 2002 & 2003 & 2004 & 2005 & 2006 & 2007 & 2008 & Total \\
\hline Generation [49] & 1788 & 1856 & 1876 & 1896 & 1896 & 2001 & 1882 & 2050 & 2000 & 17245 \\
\hline Use [ 54] & 345 & 191 & 381 & 389 & 380 & 313 & 250 & 527 & 380 & 3146 \\
\hline excess & 1443 & 1665 & 1495 & 1517 & 1517 & 1688 & 1639 & 1524 & 1620 & 14101 \\
\hline Export [ 77] & 1339 & 1550 & 1385 & 1400 & 1400 & 1560 & 1510 & 1400 & 1500 & 13044 \\
\hline
\end{tabular}

Bhutan generated 17245 million KWh, Use 3145 million KWh and exported 14101 million KWh of electricity in 9 years (2000-08). This is a one way trade in which India only imported electricity.

Chukha hydro electric power plant (336 MW) was built by the fund of Indian Government in 1988 [50]. 70\% of 1320 million $\mathrm{KWh} /$ year of generated electricity is exported to India [50]. Until 2004, the electricity rate was $1.50 \mathrm{INR}$ and after 2005 it became 2.00 INR [50].

Kurichu hydro electric power plant $(60 \mathrm{MW})$ was built by Indian Government Fund in 2002 and the rate of electricity is $1.5 \mathrm{INR} / \mathrm{Kwh}$ [48].

1020 MW Tala Hydro electric power plant, capacity 3962 million KWh/year, was funded by Indian Government at $9 \%$ interest rate and electricity rate is 1.6 INR [51].

On the other hand, Basochu hydro electric power plant (64 MW) was built by Austrian Government fund without any interest and all electricity is used only in Bhutan [52].

\subsubsection{Electricity Exchange between Myanmar and Bangladesh}

Myanmar's electricity generation capacity has increased to $1335 \mathrm{MW}$ from $706.82 \mathrm{MW}$ between 1988 and 2005 and in 2008 it generated 6.154 billion KWh of electricity [45, 53]. Myanmar uses only 3.744 billion KWh of electricity annually, so half of the generated electricity remains unused [54]. Myanmar also planned to construct 16 new hydro electric power plant, 5 of which has already completed and 11 are in under construction [30]. At the completion of those power plants, $3445 \mathrm{MW}$ power will be added to the total generation capacity of Myanmar [30]. In 2008, Bangladesh gave proposal to set a power plant in Myanmar with its' own fund [61]. According to the proposal, Bangladesh would get $70 \%$ of generated electricity from that plant and Myanmar accepted it at that time [55].
From the Above information it is clear that, India has created electricity trade with Nepal and Bhutan in the name of electricity exchange. According to above statistics, India exported more electricity to Nepal than imported electricity from Nepal. Currently Nepal is facing serious electricity scarcity problem and it is considered as the poorest country of this region having GDP growth rate of $4.6 \%$ [77]. Though Nepal has huge hydro electric potential, this electricity could not be helpful in economical development because of not having proper ownership or royalty. Nepal export its' generated electricity. On the other hand it has to import electricity at high rate from India which has a negative effect on economy. Almost all generated hydro electricity of Bhutan, 14101 million KWh of 17245 million $\mathrm{KWh}$, is exported to India.

\subsection{India's Policy of Cooperation}

All most all main rivers of Himalayan region are international; such as Shindu, Started from Tibet and flows through Pakistan and India, Mohakali, Started from Nepal and flows through India, Ganges, Started from Himalaya and flows through India and Bangladesh, Iraboti, Stars from Himalaya and flows through China and Myanmar and Yamuna flows through Tibet, India and Bangladesh [56]. These are the main source of human living in this region and about 200000 million people depend on these rivers [56]. Bangladesh has 54 and 3 common river with India and Myanmar respectively. The problem with water flow through India has not been solved yet [56]. India and china's thrust for electricity is increasing continuously and they have already started generating electricity by creating dam at Himalayan Rivers which creates serious water scarcity in other downstream countries [32]. India is planning to make huge money from this generated power 
[56]. The Government of Arunachal province (India) has said that, Arabian countries are floating on Petro Dollar and their country will float on hydro dollar [32]. 200000 million downstream people's life will be in danger for those electricity generation dams of Himalayan Rivers. That is a question of preserving human primary right, the water. Indian Supreme court stated in a suit that if ecology is hampered for creating a suitable environment of people living, consolation should be given [57]. Four main rivers of Bangladesh, Padma, Brahmaputra, Meghan and Karnafuli come from Himalaya through India. So Bangladesh will be the main victim of Indian's plan of hydro electricity generation and Bangladesh is not getting any consolation for this. India is going to export electricity in near future and the main source of this electricity are those hydro power plants which reflected in $11-15^{\text {th }}$ electricity plan of India [58].

\section{Survey on the Opinion of Electricity Trading between India and Bangladesh}

Bangladesh government has taken different policy to overcome the barrier of insufficient electricity supply to the people and electricity trade from India is one of the policies. People of Bangladesh have different opinion regarding this matter. From one point of view, it has positive effect on total electricity condition of Bangladesh. On the other hand it may have negative economical effect in far future. However a survey has been done for people opinion about different issue related to this electricity trading. A questioner has been prepared and distributed among 100 teachers of different discipline such as Economics, English, Engineering, Management, Accounting, Marketing, Tourism \& Hospitality Management of IUBAT_-Internal University of Business Agriculture and Technology for giving their opinion. From that survey we have got the following result. The first question was, "Bangladesh Government will import 250MW electricity from India by August, 2013 which will cost TK 4/Unit excluding transmission expenses. Do you think that it is a right decision?" 58\% teachers said no and only 9\% teachers said yes. $33 \%$ teachers did not give any opinion.

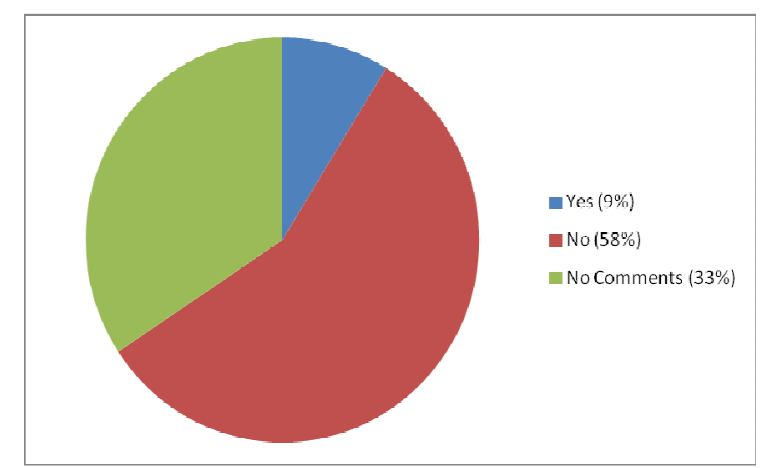

Figure 2. pi chart showing the opinion in \% on question 1
$40 \%$ teachers have given positive answer and $31 \%$ teachers have given negative answer to the question 2 which was "Including the transmission and maintenance cost, the total purchase cost of electricity from India will increase far more. Do you think that it will increase the cost per unit of electricity?"

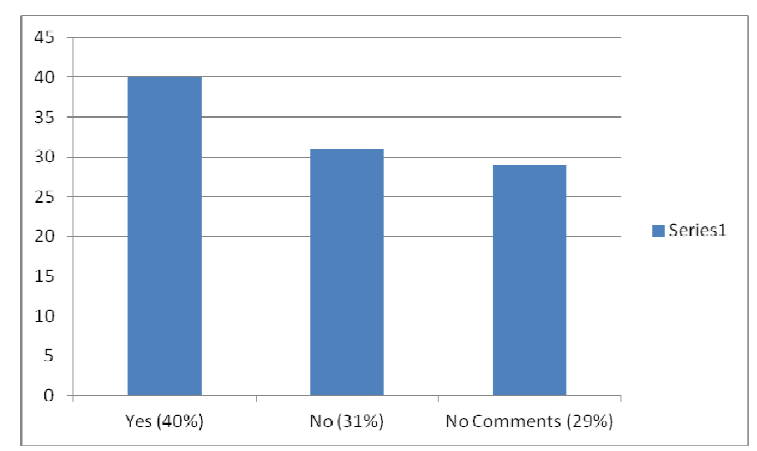

Figure 3. graph showing the opinion in \% on question 2

Only 18\% teachers agreed and 59\% teachers disagreed on question 3, "Do you think importing only $500 \mathrm{MW}$ is enough to solve the load shading problem of our country?"

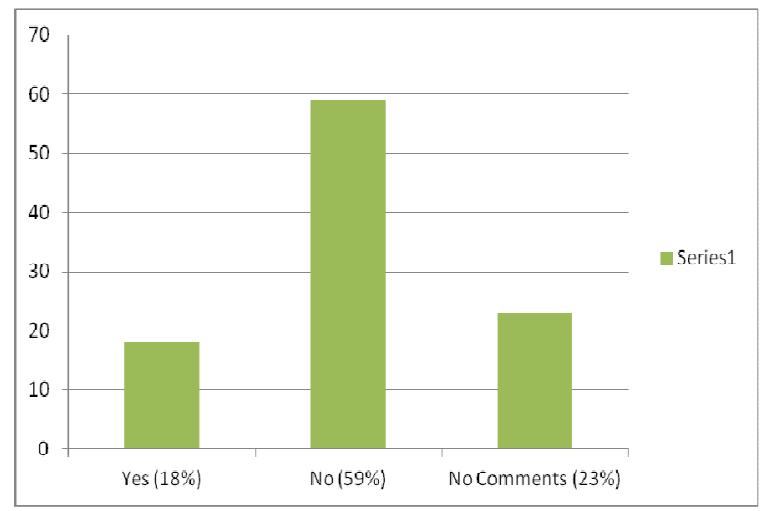

Figure 4. graph showing the opinion in \% on question 3

The 4th question was "At present, the government cannot supply electricity to many industries, residential and commercial buildings due to lack of electricity. Do you think that this problem can be solved by this imported extra power from India?" only $35 \%$ of the teachers said yes and $43 \%$ said no.

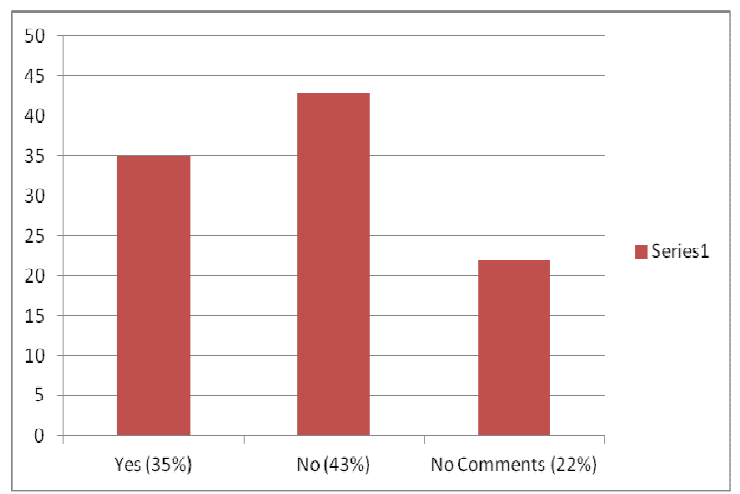

Figure 5. graph showing the opinion in \% on question 4 
In question 5 we asked that "What can be the reason for purchasing electricity from India. 17.02\% teachers think that we have lack of man power to produce enough electricity. $42.55 \%$ teachers said that we don't have sufficient money to produce electricity and $40.43 \%$ teachers think Bangladesh has limited primary fuel reserve to produce necessary electricity.

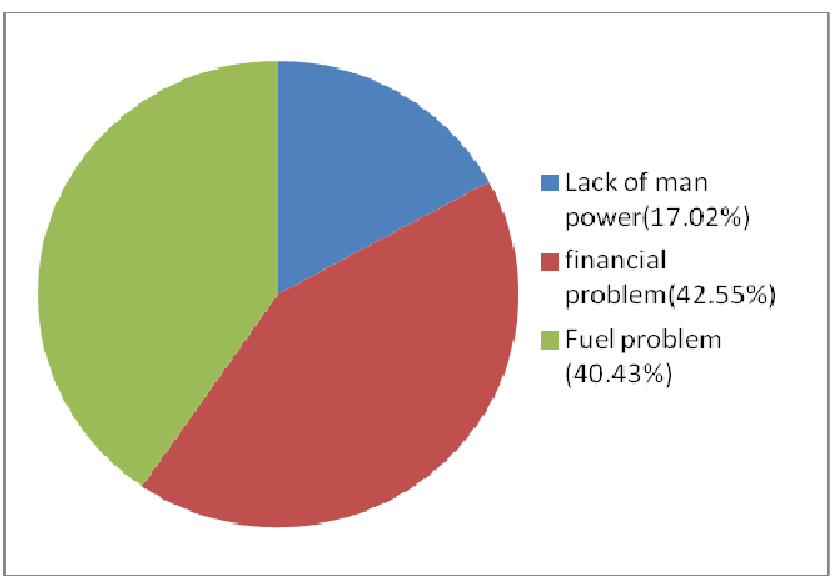

Figure 6. graph showing the opinion in \% on question 5

\section{Discussion \& Recommendation}

The main reason of electricity scarcity in Bangladesh is lack of gas supply and $770 \mathrm{MW}$ electricity generations was stopped on 22 October 2008 for this reason [5, 59, 60]. $3115 \mathrm{MW}$ of Electricity supply can be ensured by ensuring gas supply [60]. Total generation of our country will be $7000 \mathrm{MW}$ after the addition of $2130 \mathrm{MW}$ gas power plant in this year (2013) [59]. Bangladesh has sufficient coal reserve also and $37 \%$ electricity is generating by coal [59]. Only half of the reserved commercial energy is used to produce electricity in Bangladesh and contribution of renewable energy is only $22 \mathrm{MW}[59,63]$. Current minimum electricity rate is 3.33 Taka per KWh [78].

From the survey it is clear that most of the people think electricity import from India cannot solve our electricity problem properly and it has some disadvantages. Including distribution cost the tariff of imported power will be at least approximately $\mathrm{Tk}$ 6.41[79] which is far more from our current domestic rate. The history of electricity trade of different south Asian countries with India is not satisfactory and in all cases other countries were dominated. India is non cooperative in case of sharing common resources like water with other countries. Moreover, in 2007-08, India's peak demand was $108886 \mathrm{MW}$ and generation was 90973 MW and in 2027 the demand will raise up to $700000 \mathrm{MW}$ [56]. India is a power deficiency country. So export of electricity by India is quite illogical. It is a matter of question that how effective will be the electricity trade and which country will be the main beneficiary. From the above information it can be said that electricity exchange between two countries is a good idea to solve running electricity problem of Bangladesh. But the trading should be effective, clear, at the cheapest rate and beneficial to both countries and we should be careful in case of choosing trading partner. However, self sufficiency is the best policy for achieving economic development. Improper policy is the main obstructer in proper electricity generation. The government has not taken effective plan to generate electricity of its own. The government should reform the electricity sector. Bangladesh has mainly one coal based power plant of $250 \mathrm{MW}$ and 30 million ton coal remain surplus after the generation of electricity each year [3]. Huge amount of power is lost due to mismanagement of the system and it is considered as system loss where the loss in the transmission system cannot be greater than $10 \%$ as Bangladesh has moderate transmission system [64]. In 2008, total system loss was considered $21.25 \%$ where transmission loss was only $5.62 \%$ and it is possible to save $400 \mathrm{MW}$ of electricity by limiting system loss at 10\% [65]. Though the coal mine was identified in Bangladesh before the liberation war, no initiative has been taken yet by the Government for improving this sector [9]. Electricity crisis can be minimized by proper management of power generation and distribution sector of Bangladesh.

\section{Conclusion}

Though electricity connection is the precondition of sustainable development, $80 \%$ of world's un-electrified people live in South Asia [62] and $60 \%$ of Bangladeshi people are not connected to national grid [59]. Bangladesh has to earn electricity consumption rate of $383 \mathrm{KWh} /$ capita to be a middle income country [61]. Some experts thing that electricity problem of Bangladesh can be solved by exchanging electricity with neighbor countries. But the exchange condition should be logical and favorable for both countries. But Bangladesh is not enough economically solvent to purchase electricity at high rate to support the people. If the country needs to import electricity badly, it can import from Myanmar at a cheap rate. One of the duties of the government is to secure energy and electricity demand and supply at affordable rate and one steps of the government is to import electricity from India. But most of the learned people have negative thoughts about this energy trading. They think that it is not a suitable way to solve our electricity problem which will affect our economy. The problem can be solved by reconstructing energy sector management system and infrastructure to reduce the system loss. Though mutual cooperation among SAARC countries is advantageous in many aspects, right of all country involved in trading should be reserved equally. History of cooperating in such trade in South Asia are not satisfactory, on the other hand electricity rate of Myanmar is low and Bangladesh has a border with Myanmar, it is advantageous to import electricity from Myanmar. Power import from India is not only the solution to solve our electricity problem and may create a negative effect on our overall economy. 


\section{References}

[1] M.S. Alam, A. Roychowdhury, K.K. Islam and A.M.Z. Huq, A Revisited Model for the Physical Quality of Life (PQL) as a Function of of Electrical Energy Consumption. ENERGY, UK. 28 (1998), pp.-791-801.

[2] M.S. Alam, B.K. Bala, A.M.Z. Huq and M.A. Matin, A Model for Quality of life as a Function of Electrical Energy Consumption. ENERGY, UK. 16 (1991), pp.-739-745.

[3] M Samsul Alam, Vulnerable Power Sector and National Interest, Main Article present in round table dialogue, National Committee of Oil-Gas-Mine and Electricity-Port Saving, 04 January 2008. (based on the information getting by research of IEP, CUET) [in Bangla]

[4] M. Nurul Islam, Sustainability \& Energy Security for Bangladesh, Prepared for A Symposium on Bangladesh Energy Sector: The Way Forward, Organized by Ministry of Energy, Power \& Mineral Resources and GTZ-German Technical Cooperation, Dhaka, 12April 2007.

[5] BPBD (Bangladesh Power Development Board), Summary of the Daily Electricity Production, 22 November, 2008

[6] M Shamsul Alam, Suvanir, Energy Security and right of information, weekly 2000, Vol-29, November 2007 [in Bangla]

[7] B.D. Rahmatullah, Vision Bangladesh-2021: Energy and Power Crisis - Reform Attempt For Sustainable Development (Power point), 21 January, 2008.

[8] Khatib, H., and M. Munasinghe, "Electricity, the Environment and Sustainable World Development", Paper presented at the $15^{\text {th }}$ Congress of the World Energy Council, Madrid, September, 1992.

[9] M. Jamaluddin, SAARC Regional Trade Study: Country Report - Bangladesh, February, 2008.

[10] Mahendra P Lama, Mohan Man Sainju, and Q K Ahmad, "Reforms and Power Sector in South Asia: Scope and Challenges for Cross-Border Trade", Economic Development in South Asia (edited by Mohsin Khan), Tata McGraw-Hill, New-Delhi, 2005.

[11] Saleque Sufi, "The Rationale of SAARC Energy Ring”, Vol. 6 (17), pp. 1-5, Power \& Energy, Dhaka, February, 2009.

[12] Country Comparison $>$ Population, Source: CIA World Fact book, 1 January, 2008, www.indexmundi.com $/ \mathrm{g} / \mathrm{r}$.aspx? $\mathrm{t}=0 \& \mathrm{v}=21 \& \mathrm{l}=\mathrm{en}$

[13] Country Comparison> Population growth rate, Source: CIA World Factbook, 1 January, 2008, www.indexmundi.com $/ \mathrm{g} / \mathrm{r}$.aspx $? \mathrm{t}=0 \& \mathrm{v}=24 \& \mathrm{l}=\mathrm{en}$

[14] List of countries by GDP (nominal) per capita, source: The World Fact book, Central Intelligence Agency for the year 2008, Wikipedia, the free encyclopedia. en.wikipedia.org/wiki/List_of_countries_by_GDP_(nominal )_per_capita

[15] Country Comparison > GDP - real growth rate, Source: CIA World Factbook, 1 January, 2008, www.indexmundi.com $/ \mathrm{g} / \mathrm{r}$.aspx? $\mathrm{t}=0 \& \mathrm{v}=66 \& \mathrm{l}=\mathrm{en}$

[16] Country Comparison > Natural gas - proved reserves, Source:
CIA World Fact book, 1 January, 2008, www.indexmundi.com $/ \mathrm{g} / \mathrm{r}$.aspx $\mathrm{t}=0 \& \mathrm{v}=98 \& \mathrm{l}=\mathrm{en}$

[17] Oil - proved reserves Country Comparison, Source: CIA World Fact book, 1 January, 2008, www.indexmundi.com $/ \mathrm{g} / \mathrm{r}$.aspx $? \mathrm{t}=0 \& \mathrm{v}=97 \& \mathrm{l}=\mathrm{en}$

[18] Proved recoverable coal reserves at end-2006, Coal, Wikipedia, the free encyclopedia, Accesses March 2009, en.wikipedia.org/wiki/Coal\#Production_trends

[19] Country Uranium reserves in tones, Uranium reserves, Wikipedia, the free encyclopedia, Accessed March 2009, en.wikipedia.org/wiki/Uranium_reserves

[20] Myanmar to produce an additional 260 million tons of coal, Published in ELEVEN no. 1 News Media in Myanmar, 02 July 2013, http://elevenmyanmar.com/national/2654-myanmar-to-produ ce-an-additional-260-million-tons-of-coal

[21] Rediff India Abroad, Pakistan has 1000 uranium reserve, 14 April, 2007, http://www.rediff.com/news/2007/apr/14pak.htm

[22] Future Projects, Export oriented projects, www.aseanenergy.org/energy/sector/electricity/myanmar

[23] The hkskyline, Honkong, "South Asia Plagued by Electricity Shortages", 31 May 2006, www.skyscrapercity.com/archive/index.php/t-356380.html

[24] The Peoples Daily Online, "China has huge potential in hydroelectric generation", 24 October 2005 , http://webcache.googleusercontent.com/search?q=cache:http ://english.peopledaily.com.cn/200510/24/eng20051024_216 366.html

[25] Country Comparison $>$ Electricity - imports, Source: CIA World Factbook, 1 January, 2008, www.indexmundi.com $/ \mathrm{g} / \mathrm{r}$.aspx $\mathrm{t}=0 \& \mathrm{v}=83 \& \mathrm{l}=\mathrm{en}$

[26] Country Comparison $>$ Electricity - exports, Source: CIA World Factbook, January 1, 2008, www.indexmundi.com $/ \mathrm{g} / \mathrm{r}$.aspx $? \mathrm{t}=0 \& \mathrm{v}=82 \& \mathrm{l}=\mathrm{en}$

[27] Reuters, "UES to Increase Electricity Export to China this Year", The Russia Journal, 17 May 1999. www.russiajournal.com/node/807.

[28] The CHINA.ORG.CN, "China to Import Electric Power from Bordering Countries”, 19 June, 2006. www.china.org.cn/english/BAT/171947.htm

[29] The People's Daily Online, "Vietnam to import electricity from China till 2010", 22 August, 2006 english.peopledaily.com.cn/200608/17/eng20060817_29384 9.html.

[30] Juliet Shwe Gaung, Hydro leads way in power generation, Myanmar times special feature, July 2008, www.mmtimes.com/feature/energy08/eng005.htm

[31] Samira Kalam, "Energy 2050: Commercial Energy Flow in South Asia", A paper submitted for partial fulfillment of the degree of M-Phill in Institute of Energy Technology, CUET, Chittagong.

[32] Shripad Dharmadhikary, "Mountains of concrete, Dam building in the Himalayas", Published by International Rivers- a non-governmental organization, December 2008, www.internationalrivers.org/files/attached-files/ir_himalaya s_rev.pdf 
[33] Bhutan , UN data a world of information (Source: World Statistics Pocketbook | United Nations Statistics Division), Accessed March 2009, data.un.org/CountryProfile.aspx?crName=Bhutan

[34] Nepal, UN data a world of information (Source: World Statistics Pocketbook | United Nations Statistics Division). Accessed March 2009, data.un.org/CountryProfile.aspx?crName=Nepal

[35] Ceylon Electricity Board, Colombo, Sri Lanka, "Statistical Digest, 2006".

[36] Sri Lanka, UN data a world of information (Source: World Statistics Pocketbook | United Nations Statistics Division). Accessed March 2009 , data.un.org/CountryProfile.aspx?crName=Sri Lanka

[37] Afghanistan, UN data a world of information (Source: World Statistics Pocketbook | United Nations Statistics Division). Accessed March 2009, data.un.org/CountryProfile.aspx?crName=Afghanistan

[38] Ministry of Energy \& Water, Islamic Republic of Afghanistan, "Power Sector Strategy for the Afghanistan National Development Strategy (with focus on prioritization)", April 2007.

[39] Islamic Republic of Afghanistan Ministry of Energy \& Water," Power sector Strategy for The Afghanistan National Development Strategy", 2007

[40] President of Maldives, "Maldives is the first carbon free country of Bangladesh", report of the Daily Prothom Alo (Bangla daily), pp 6, 24 March, 2009.

[41] Maldives, UN data a world of information (Source: World Statistics Pocketbook | United Nations Statistics Division) Accessed March 2009, data.un.org/CountryProfile.aspx?crName=Maldives

[42] British Petroleum, "Natural gas reserves table: Natural gas reserves", 2008 www.bp.com/liveassets/bp_internet/globalbp/globalbp_uk_e nglish/reports and publications/statistical energy review_2 008/STAGING $\bar{G} /$ local_assets/downloads/pdf/gas table_of $\overline{p r}$ oved_natural_gas_reserves_2008.pdf

[43] Background paper, Central Asia/South Asia Electricity Trade Conference, Islamabad, Pakistan, May 8-9, 2006.

[44] The Bangladesh News.Com (Online news paper), "Coal can change the economy of Bangladesh", March 2009, www.bangladeshnews.com/bd

[45] The People's Daily Online, "Myanmar raises electricity charge prices", May 2006, english.peopledaily.com.cn/200605/22/eng20060522_26760 4.html

[46] Dwarika N. Dhungel, "Energy, Reforms and Cross-border Cooperation between Nepal and India: A Professional Perspective", A paper submitted for a dialogue programme on economic reforms and development dynamics: A cross borders perspective between India and Nepal, Organized by University of Sikkim, Gangtoc, April 18-20, 2008.

[47] Rabin Subedi \& Ratan Bhandari, February 2008, w4pn.org/index.php?option $=$ com_content\&task=view\&id $=5$ $3 \&$ Itemid $=30$
[48] The Bhutan News Online, "KURICHHU HYDRO-ELECTRIC PROJECT", 06 April, 2005. www.bhutannewsonline.com/kurichhu hydroproject.html

[49] Bhutan - Electricity - production (Source: CIA World Factbook, 1 January, 2008, www.indexmundi.com/g/g.aspx?c=bt\&v=79

[50] The Bhutan News Online, "Chukha Hydro Power Corporation (CHPC)", 6 April, 2005. www.bhutannewsonline.com/chukha_hydro.html

[51] The Bhutan News Online, "Tala Hydroelectric Project $\begin{array}{llll}\text { Authority } & \text { (THPA), } & 06 & \text { April, }\end{array}$ www.bhutannewsonline.com/tala_hydroproject.html

[52] The Bhutan News Online, "Basochu Hydro Power Project", 06 www.bhutannewsonline.com/basochu_hydro.htm April, 2005.

[53] Burma - Electricity - production (Source: CIA World Factbook, 1 January, 2008, www.indexmundi.com/g/g.aspx? $\mathrm{c}=\mathrm{bm} \& \mathrm{v}=79$

[54] Burma - Electricity - consumption (Source: CIA World Factbook, 1 January, 2008, www.indexmundi.com/g/g.aspx?c=bm\&v $=81$

[55] Asean Affairs, "Hydro Power Project: Myanmar agrees to push Bangladeshi's proposal", 9 October, 2008, www.aseanaffairs.com/hydro_power_project_myanmar_agr ees_to_push_bangladeshi_s_proposal

[56] Weekly (weekly magazine) 552 dam of India Pakistan Nepal Bhutan and hydro electricity politics of India, pp 30-42, 19 February, 2009.

[57] M Shamsul Alam, Coal: Environment in improving minr, the Daily Somokal 21 October, 2007 [in Bangla]

[58] Interim Report of the Independent People's Tribunal (IPT) on Dams in Arunachal Pradesh, India. 3 February 2008. [ http://www.iptindia.org ]

[59] PDB, "An open discussion on planning of power generation increase, Demand side management \& system loss reduction", A power point presentation in BERC meeting, Dhaka, 16 April, 2009.

[60] M. Fouozul Kabir Khan, Energy sector: Challenges of Adding New Capacity, A paper presented in the conference on Development With Equity and Justice, organized by Centre for Policy Dialogue (CPD), Dhaka, 28-29 March 2009.

[61] Planning Commission, Government of Bangladesh, Development Parameters of Bangladesh Present Vs. MI and UMI References for Background Papers, Outline Participatory Perspective Plan (OPPP) Project 2007-2021, 2008.

[62] Electricity for all: Targets, timetables, instruments, An initiative to make electricity available, accessible and affordable to all: Proposal for a global debate, GENI (Global Energy Network Institute), October 2002, www.geni.org/globalenergy/library/media_coverage/electricitede-france/electricity-for-all--targets-timetables-instuments.shtml

[63] B.D. Rahmatullah, Study on Critical Factors in Determining Success of Renewable Energy Projects in South Asia, A Country Report-Bangladesh, November 2008. 
[64] M.S. Alam, E.Kabir, M.M. Rahman, M.A.K. Chowdhury, "Power sector reform in Bangladesh: Electricity distribution system”, ENERGY, UK. 29 (2004), pp.-1773-1783.

[65] B. D. Rahmatullah, Vulnerability of Power Sector, way of solving problem and vision 2021, Dr. Golam Mohiuddin memorial speech, Bangladesh Udichi Shilpi Gosti, 24 April, 2009. [in Bangla]

[66] Trading Economics, Babgladesh GDP Grouth Rate, www.tradingeconomics.com/bangladesh/gdp-growth,2013

[67] REUTER, "Bangladesh to import $250 \mathrm{MWh}$ power/day from India, $\quad 18$ February 2013, in.reuters.com/article/2013/02/18/bangladesh-power-india-i dINDEE91H0AS20130218,

[68] Power and Energy Sector Road Map : An Update, Finance Division, Ministry of Finance Government of People's Republic of Bangladesh, Accessed December 2012, www.mof.gov.bd/en/budget/11_12/power/power_energy_en. pdf, 2011

[69] The EnergyBangla (online news paper), 13 November 2013, www.energybangla.com/2013/04/17/2626.html\#.UXY1glJ4r $\mathrm{CM}$,

[70] Global Transmission Report, "Project Updates", gust 22, 2013, www.globa ltransmission.info/archive.php?id=3976, $\mathrm{Au}$

[71] Bangla News 24.com, "Power Import from India in July",
January 31, 2013, www.banglanews24.com/English/detailsnews.php?nssl=21e 7a3199904eacbfc122e0e681 c6aba\&nttl=2013013163262,

[72] Business Recorder, "Bangladesh to import 250 megawatts-hours a day from India", February 19, 2013, http://www.brecorder.com/fuel-a-energy/193/1155498/

[73] Power Grid Company of Bangladesh Ltd, National Load Dispatch Center, Daily Report, www.bpdb.gov.bd/bpdb/pdb_utility/maxgen/dailygen_archi ve/2019page1.pdf

[74] AHM. Mustain Billah, Energy and Environment: Demand for Wood Energy in Bangladesh, SEMP-SDN Project, Bangladesh Institute of Development Studies (BIDS), www.sdnbd.org/sdi/issues/energy/publications/energy_and_ environment.htm

[75] International Monetary Fund, IMF Country Report No.12/326, Nepal, 2012 ARTICLE IV CONSULTATION, December 2012, www.imf.org/external/pubs/ft/scr/2012/cr12326.pdf,

[76] Country Comparison $>$ Electricity - consumption, Source: CIA World Factbook, 1 January, 2008, www.indexmundi.com $/ \mathrm{g} / \mathrm{r}$.aspx? $\mathrm{c}=\mathrm{pk} \& \mathrm{v}=81$

[77] Bhutan - Electricity - exports, Source: CIA World Factbook, January 1, 2008, www.indexmundi.com $/ \mathrm{g} / \mathrm{g}$. aspx ? $\mathrm{v}=82 \& \mathrm{c}=\mathrm{bt} \& \mathrm{l}=\mathrm{en}$ 